Boise State University

ScholarWorks

$12-1-2017$

\title{
Commentary: Research Recommendations for Understanding the Decline of American Kestrels (Falco sparverius) Across Much of North America
}

Christopher J.W. McClure

Peregrine Fund

Sarah E. Schulwitz

Peregrine Fund

Richard Van Buskirk

Pacific University

Benjamin P. Pauli

Boise State University

Julie A. Heath

Boise State University 


\title{
SHORT COMMUNication
}

J. Raptor Res. 51(4):455-464

(C) 2017 The Raptor Research Foundation, Inc.

\section{Commentary: Research Recommendations for Understanding the Decline of American Kestrels (Falco sparverius) Across Much of North America}

\author{
Christopher J.W. McClure ${ }^{1}$ and SARAh E. Schulwitz \\ The Peregrine Fund, 5668 West Flying Hawk Lane, Boise, ID 83709 U.S.A.
}

RichaRd VAN BUSKIRK

Department of Environmental Studies, Pacific University, 2043 College Way, Forest Grove, OR 97116 U.S.A.

\author{
Benjamin P. Pauli ${ }^{2}$ and Julie A. Heath \\ Department of Biological Sciences and Raptor Research Center, Boise State University, 1910 University Drive, Boise, ID \\ 83725 U.S.A.
}

KEY WORDS: American Kestrel; Falco sparverius; full-annualcycle model; migration counts; monitoring; nest cavity; population decline, raptor, research priorities.

Across much of North America, populations of American Kestrels (Falco sparverius) have been in decline for decades (Farmer et al. 2008, Farmer and Smith 2009, Smallwood et al. 2009a, Paprocki et al. 2014, Sauer et al. 2014). Hypothesized causes of kestrel declines include predation by Cooper's Hawks (Accipiter cooperii; Farmer et al. 2008), pathogens (e.g., Nemeth et al. 2006), habitat loss (Sullivan and Wood 2005, Farmer et al. 2008, Bolgiano et al. 2015), pesticides (Smallwood et al. 2009a, Rattner et al. 2015), and climate change (Steenhof and Peterson 2009b), yet no hypothesized factor has been supported empirically (Farmer et al. 2006, Smallwood et al. 2009a). Despite the effort spent evaluating threats, the lack of a "smoking-gun" to explain the decline of this charismatic species has led many professional and citizen scientists to call for action on several unlikely, and unsupported, threats. Here, we evaluate and build on hypothesized causes of declines considered by other authors (e.g., Sullivan and Wood 2005, Farmer et al. 2008, Smallwood et al. 2009a) to synthesize conclusions and articulate research needs.

American Kestrels are among the most extensively monitored raptors in North America. Yet even with evidence for regional declines across large parts of the continent (Farmer et al. 2009a, Paprocki et al. 2014, Sauer et al. 2014), population trends are not clear in all regions.

\footnotetext{
${ }^{1}$ Email address: cmcclure@peregrinefund.org

${ }^{2}$ Present address: Biology Department, Saint Mary's University of Minnesota, 700 Terrace Heights, Winona, MN 55987 U.S.A.
}

For example, in the western U.S., migration counts indicate that declines began in the late 1990s (Farmer et al. 2008, Farmer and Smith 2009), whereas data from the National Audubon Society's Christmas Bird Count (CBC, Butcher 1990) indicate an opposing pattern of the population declining from 1975 until the late 1990s, followed by recent stabilization (Paprocki et al. 2014). The North American Breeding Bird Survey (BBS, Sauer et al. 2014), meanwhile, showed a steady decline through 2013 across much of the western U.S. since data collection began in the late 1960s (Fig. 1A). Conflicting trends among datasets make it difficult to determine drivers of decline. Thus, attention should be paid to potential reasons trends might differ among datasets and situations where trends in monitoring might become decoupled from actual population levels.

Here, we examine what is known about the decline of the American Kestrel to identify avenues of research that may elucidate the cause, or causes, of decline. We also highlight areas of research that would increase the utility of different monitoring programs because trends in monitoring data can lend important insight into the cause of a decline (Mace et al. 2008, Di Fonzo et al. 2013, Shoemaker and Akçakaya 2014). Our research recommendations present an evidence-based path forward toward a demographic understanding of the decline of North America's smallest falcon.

\section{A Mysterious Decline}

The preponderance of the evidence suggests "we have been observing prolonged, steady declines" (Smallwood et al. 2009a) in many populations of American Kestrels. Indeed, data from the BBS indicate that many popula- 

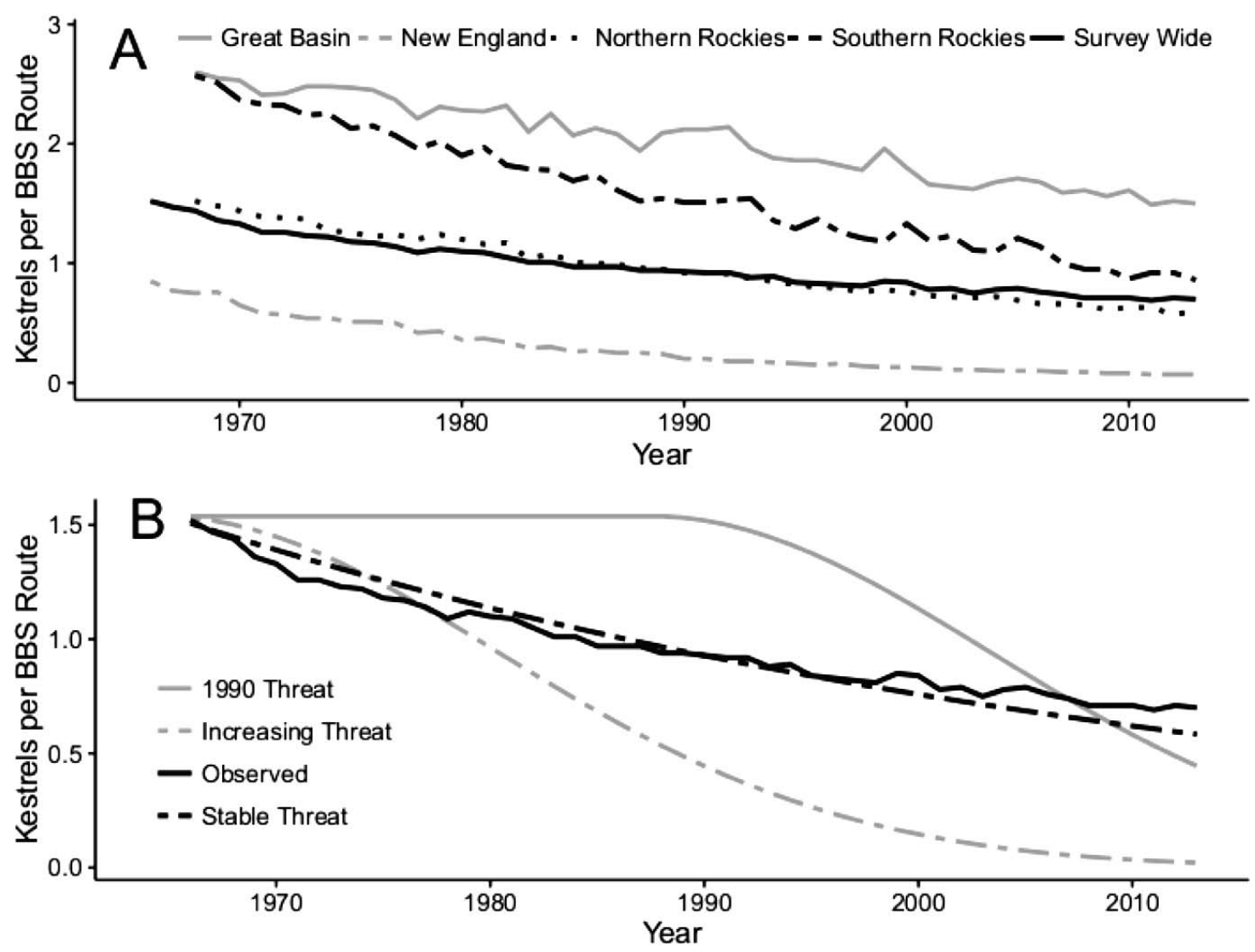

Figure 1. (A) Average abundance of American Kestrels observed per year along Breeding Bird Survey (BBS) routes with results for select Bird Conservation Regions broken out. Estimates are derived from Sauer et al. (2014). (B) Expected trends in populations of American Kestrels if declines were caused by decreased adult survival (0.01 per year) starting in 1990 (1990 Threat), steadily decreasing adult survival (0.01 per year) since 1966 (Increasing Threat), and depressed but constant survival (95\% of base value) since 1966 (Stable Threat). Base values of vital rates were those used by McClure et al. $(2017$, adult survival $=0.4$, juvenile survival $=0.1$, fecundity $=1.6$, and immigration $=0.44)$. Note that expected trends would be similar regardless of which vital rate is depressed. For reference, we also present the observed survey-wide trend in BBS data for American Kestrels (survey-wide BBS) derived from Sauer et al. (2014).

tions have been declining consistently since data collection began in the late 1960s (Fig. 1A). Data from several nest-box programs also show a steady decline (Smallwood et al. 2009a). Paprocki et al. (2014) examined data from the CBC in western North America and found that counts of wintering American Kestrels declined from the mid1970 s through the mid-1990s and then reached a plateau. However, to be useful, trends in data from monitoring programs must generally be positively correlated with actual population levels. If this assumption of positive correlation is violated, it is difficult to clearly discern the rate and scope of declines. Observed changes in kestrel biology over the past decade might decouple population indices from true population levels. For example, in western North America, changes in migration distance have caused the wintering distribution of the American Kestrel to shift northward in recent decades, which is affecting apparent trends in data collected by the CBC (Paprocki et al. 2014). Likewise, observed changes in kestrel phenology induced by climate change (e.g., Steenhof and Peterson 2009b, Heath et al. 2012, Van Buskirk 2012, Smith et al. 2016) may alter the detection rate of kestrels during fixed-date annual surveys, potentially inducing trends in yearly counts (Simons et al. 2007, McClure et al. 2011, Heath et al. 2012). Studies of nestbox occupancy are also potentially problematic because changes in the availability of suitable habitat in surrounding areas may induce false trends in occupancy (VanCamp and Henny 1975, Hayward et al. 1992, McClure et al. 2017). 
In addition to changes in kestrel distribution and behavior, differences in methods and target populations might lead to conflicting trends in population indices. For example, migration counts and the BBS have inherently different sampling methods (i.e., counts from fixed monitoring stations along migration routes vs. roadside sampling during breeding season), which may explain differences among trends (Bednarz et al. 1990, Farmer et al. 2007). It is often uncertain which breeding populations are sampled during migration counts; changes in migratory patterns, as observed for the American Kestrel (e.g., Van Buskirk et al. 2009, Heath et al. 2012, Van Buskirk 2012, Paprocki et al. 2014), can confound interpretation of longterm population trends (Fuller and Mosher 1981, Viverette et al. 1996), making it difficult to compare to breedingseason data. For example, through 2013 trends in BBS data from western Bird Conservation Regions including the Northern and Southern Rockies and the Great Basin, among others, all showed steady declines since data collection began in the late 1960s (Fig. 1A). This trend is in contrast with the steepening declines observed at western hawk watch sites since the mid-1990s (Farmer et al. 2008, Farmer and Smith 2009). It is unclear if this dissimilarity is due to actual differences in trends of the populations surveyed or changes in biological patterns, such as decreased migration tendency due to climate change, causing relationships between data collected and population trends to be decoupled. Although BBS data are imprecise for many raptors because of low density and detectability, the American Kestrel is an exception because it has relatively high detectability and occurs near roads (Farmer et al. 2007). Further, BBS data allow assessments of specific regional populations. We therefore view migration counts as a valuable supplement to BBS data (see Dunn et al. 2005) for the American Kestrel, but inferences from either program must consider the methods employed (Nolte et al. 2016), the populations sampled, and potential changes in behavior and distribution.

\section{UNKNOWN CAUSES}

To identify potentially fruitful avenues of research, we must consider evidence for hypothesized causes of decline. Smallwood et al. (2009a) quantitatively discounted predation by Cooper's Hawks as a potential general cause of decline and qualitatively discounted habitat loss and environmental contaminants within their study sites as a cause of decline for their nest-box populations. Importantly, Smallwood et al. (2009a) noted that West Nile virus was unlikely to be a cause of decline because it arose in the 1990s, whereas kestrels have been declining since at least the 1960s.

Recent evidence suggests that neonicotinoid pesticides have contributed to population declines of farmland birds in the Netherlands (Hallmann et al. 2014). It is possible, albeit untested, that these pesticides also affect populations of American Kestrels. Yet, these pesticides came into use in the mid-1990s (Mineau and Palmer 2013), eliminating them from contention as the singular cause of kestrel population declines. There are many other potential threats that have arisen since American Kestrels began declining, and population recovery certainly might depend on managing these new threats. However, any threat that appeared after the 1960 s did not initiate or noticeably alter the rate of decline observed in populations of American Kestrels (Fig. 1B).

Although Smallwood et al. (2009a) quantitatively tested, and rejected, the hypothesis that predation by Cooper's Hawks is causing kestrel declines, this hypothesis is perhaps the most often suggested to us by both professional and citizen scientists. The pattern of the kestrel decline can also help to examine the Cooper's Hawk hypothesis. The increase in Cooper's Hawks has occurred mostly since the 1970s (Farmer et al. 2008, Sauer et al. 2014), and one would assume that if Cooper's Hawks were a threat to populations of American Kestrels that those populations would decline faster as Cooper's Hawks increased. Yet, declines of kestrel populations do not seem to be accelerating (Fig. 1B). It is possible that increasing predation is indeed causing systematic changes in survival, but the changes are so slight that the effect on observed population growth rates has remained relatively constant, or that predation by Cooper's Hawks only affects populations locally.

Destruction and alteration of breeding habitat is a potential threat to many species and the American Kestrel is no exception (Sullivan and Wood 2005, Farmer et al. 2008, Smallwood et al. 2009a, Wommack et al. 2014, Bolgiano et al. 2015). American Kestrels are secondary cavity nesters (Smallwood and Bird 2002) and several studies have demonstrated population increases after the installation of nest boxes (Nagy 1963, Hamerstrom et al. 1973, Stahlecker and Griese 1979, Bloom and Hawks 1983, Wilmers 1983, Toland and Elder 1987, Smallwood and Collopy 2009), leading some to suggest that a lack of nest cavities might be causing population declines (Sullivan and Wood 2005). However, that occupancy of nest boxes is declining at several locations across North America (Smallwood et al. 2009a) suggests that those populations are not limited by nest sites and therefore that a loss of nest cavities is not a cause of decline in those areas (McClure et al. 2017) - i.e., previously productive breeding sites should not be vacant if nest sites are limiting.

It is possible that several threats, including those mentioned above, arose and subsided over time, interacting in such a way as to produce an apparently steady decline in breeding populations of American Kestrels across most of North America. Multiple threats could also combine additively to affect vital rates (Bolgiano et al. 2015), and kestrel populations might be facing region-specific threats (Wommack et al. 2014). Indeed, although many breeding populations of American Kestrels are declining at different rates, BBS data show those rates remained relatively steady since monitoring began through 2013 (Sauer et al. 2014). 
These potentially complicating aspects of kestrel ecology highlight that easy answers to kestrel declines are elusive. The most parsimonious demographic mechanism underlying a slow and steady decline seems to be that one or more vital rates (reproduction or survival) are consistently depressed (Fig. 1B). That vital rates would remain unchanged since the 1960 s seems extraordinary, however, given the various dynamic threats faced by populations of birds (e.g., Loss et al. 2015). Therefore, the most concise statement we can make regarding what is known about the underlying cause of kestrel declines is that consistently too many kestrels seem to be dying relative to the number fledged each year.

\section{A PATH FORWARD}

Monitoring. Differences among population trends generated by disparate monitoring methods within regions highlight the enigmatic nature of kestrel declines and the need to evaluate the potential situations where population indices do not track population levels. Count data such as the BBS, $\mathrm{CBC}$, and migration counts provide important information regarding population trends, but research should be conducted to bolster their inference. For example, given the documented effects of climate change on the phenology and distribution of the American Kestrel (e.g., Van Buskirk et al. 2009, Heath et al. 2012, Van Buskirk 2012, Paprocki et al. 2014, Smith et al. 2016), researchers should consider the possibility of false trends being induced by changes in kestrel distribution (Paprocki et al. 2014) or detectability (Simons et al. 2007, McClure et al. 2011, Heath et al. 2012). Studies using tracking devices (e.g., geolocators; Bächler et al. 2010), or DNA (e.g., single nucleotide polymorphisms; Ruegg et al. 2014) can also examine migratory connectivity, thereby elucidating which breeding populations are being sampled at hawk watch sites and by CBC circles.

Standardized counts of adult birds (BBS, CBC, migration counts) can also be problematic because of their limited historical reach relative to the time frame for changes in the size of kestrel populations. The earliest large-scale standardized monitoring of American Kestrels began in 1966 with the inception of the BBS, when kestrels seemed to be already in decline. It is therefore unknown when most populations of the American Kestrel began declining. Researchers should consider indirect methods such as atlas data or historical accounts to determine how long kestrels have been in decline. For example, Greenberg and Droege (1999) used data from atlases and historical descriptions of abundance to demonstrate that Rusty Blackbirds (Euphagus carolinus) had been in decline since the 1800s. Like the Rusty Blackbird, the American Kestrel is widespread, declining, and often mentioned in historical accounts (C. McClure unpubl. data). The methods employed by Greenberg and Droege (1999) might therefore be employed for the American Kestrel. Determining historical trends in kestrel populations might allow researchers to test hypotheses regarding the original causes of decline, and put the current trends into a more longterm perspective.

Monitoring of nest boxes by professional and citizen scientists has the potential to generate tremendous amounts of fine-scale data on kestrel occurrence suitable for aggregation and analysis across its breeding range (e.g., The Peregrine Fund's American Kestrel Partnership, www. kestrel.peregrinefund.org). However, the ability of changes in the availability of unmonitored nest cavities to induce misleading trends in nest-box data is underappreciated and should be investigated. For example, McClure et al. (2017) demonstrated that if the availability of natural cavities decreases, occupancy of nest boxes might actually rise because the nest boxes would make up a higher proportion of available nest sites (see also VanCamp and Henny 1975, Hayward et al. 1992). Conversely, occupancy of established nest-box programs might decline if private citizens erect nest boxes nearby, unbeknownst to managers of established programs (McClure et al. 2017). Researchers should therefore develop analytical and experimental methods such as the simulations used by McClure et al. (2017) to aid in the interpretation of trends in nest-box occupancy. Further, researchers should foster open communication with citizens monitoring private boxes near a professional study site.

Studies to improve inference from monitoring data will help to clarify the spatial and temporal scope of kestrel declines, but in the meantime researchers must use existing methods for inference into the extent of the decline. Researchers should develop methods to integrate information from different kestrel monitoring programs into a composite index. Butcher and Niven (2007) combined BBS and $\mathrm{CBC}$ data for improved inference into bird population trends. Van Strien et al. (2001) combined data from national bird-monitoring programs in Europe that had different protocols into a composite index that spanned across countries. Paprocki et al. (2017) used data from the Raptor Population Index (Bildstein et al. 2008) and CBC to examine population trends for Red-tailed Hawks (Buteo jamaicensis) across North America. The states of Florida (Florida Fish and Wildlife Conservation Commission [FFWCC] 2013) and New Jersey (Smallwood et al. 2009b) have statewide nest-box monitoring programs and The Peregrine Fund's American Kestrel Partnership coordinates a citizen science nest-box project across the western hemisphere. These large-scale nest-box programs could be combined with count data such as the BBS to gain more robust inference into population trends. Researchers might then target regions with strong evidence of a decline for studies of survival and reproduction to develop a demographic understanding of the decline of the American Kestrel. Scientists and analysts could also examine trends across different bird conservation regions to target areas for demographic studies (e.g., Stanton et al. 2016), 
including areas with stable populations for comparison purposes.

Studies of Survival. Smallwood et al. (2009a) noted that because populations using nest boxes were declining despite seemingly stable habitat conditions and observed high reproductive rates, the cause of declines may be increased mortality during the nonbreeding season. Threats during the breeding season have been the most hypothesized causes of decline (Sullivan and Wood 2005, Farmer et al. 2008, Smallwood et al. 2009a). Further, population growth rates for longer-lived species such as raptors are generally most sensitive to changes in adult survival (e.g., Hiraldo et al. 1996, Sæther and Bakke 2000, Clark and Martin 2007). Efforts to examine rates and drivers of survival of American Kestrels outside of the breeding season are therefore needed and may lend useful insight into important drivers of decline. Although there have been many studies of return rates using nest boxes (e.g., Katzner et al. 2005, Miller and Smallwood 2009, Steenhof and Heath 2009, 2013, Steenhof and Peterson 2009a), and some using radiotelemetry to examine mortality (e.g., Varland and Loughin 1993a, Farmer et al. 2006, Stupik et al. 2015), we are aware of few studies estimating yearly survival of American Kestrels (Bortolotti et al. 2002, Hinnebusch et al. 2010, Brown and Collopy 2013). Operators of nest-box programs should therefore consider banding both nestlings and adults to estimate apparent yearly survival of both age classes. Estimates of seasonal survival, particularly outside of the breeding season, are sorely needed and could be quantified using bands or other tracking devices (e.g., Varland and Loughin 1993a, Farmer et al. 2006, Stupik et al. 2015).

Similarly, examinations of migratory connectivity and identification of important migratory routes and wintering grounds south of the U.S. would help determine whether mortality outside of the breeding season is a cause of decline. Goodrich et al. (2012) noted that American Kestrels are ideal for studies of migratory connectivity using band returns because they are easily captured during the breeding season. Indeed, there have been several studies using band returns to examine kestrel migration (e.g., Duncan 1985, Henny and Brady 1994, Hoffman et al. 2002). Yet only a small fraction of the band encounter records for American Kestrels are south of the U.S. (C. McClure unpubl. data), despite thousands of kestrels migrating south of the U.S. every year (Bildstein 2004, Lott 2006). Latin America and the Caribbean are therefore perhaps underappreciated wintering grounds for kestrels that breed in parts of North America. Important wintering areas might be identified using ebird (www.ebird.org) data and migratory connectivity might be examined using tracking devices or genetic sampling.

Studies of Reproduction. The ease with which kestrels are monitored and studied using nest boxes has resulted in a wealth of research regarding the breeding ecology of the American Kestrel. Differences between natural and artificial nest sites regarding productivity, imprinting (Brown and Collopy 2013), and dispersal are important in predicting the effects of management using nest boxes. Unfortunately, nests within natural cavities are difficult to locate and monitor. Some studies have suggested that nest success is similar for American Kestrels using natural cavities and nest boxes (Craig and Trost 1979, Toland and Elder 1987), but more research is needed to determine the conditions where nest success might differ between natural and artificial sites. Programs monitoring both nest boxes and nearby natural cavities would serve to elucidate differences between the two substrates. Although natural cavities are difficult to locate and access, there are protocols that might be employed and tailored for American Kestrels (e.g., Dudley and Saab 2003).

There are many kestrel nest-box programs across North America, often with different protocols for erecting and monitoring boxes. Standardization of protocol would help to make results interpretable across studies (Lambrechts et al. 2012). In general, programs should strive to check boxes multiple times throughout the breeding season, either at regular intervals or at important time points. For example, researchers might check boxes during the egg stage and then return when eggs are assumed to have hatched. Estimating the age of nestlings using published aging guides (Griggs and Steenhof 1993, Klucsarits and Rusbuldt 2007) would allow researchers to approximate the date of nest initiation and to know when nestlings will be roughly $22 \mathrm{~d}$ old. Nests containing nestlings $>22 \mathrm{~d}$ old are generally considered to be successful (e.g., Steenhof and Peterson 2009b); therefore, checking nests around that time would allow researchers to estimate the number of fledglings. Of course, researchers should take care not to cause premature fledging.

Researchers should also examine drivers of nest success within nest boxes. For example, Varland and Loughin (1993b) noted that nest success of kestrels using nest boxes placed along an interstate highway in Iowa was similar to that of other, non-roadside nest-box programs. However, Strasser and Heath (2013) documented higher nest failure in boxes that experienced increased levels of road traffic, likely because of increased noise. The utility of roadside nest boxes as management tools for American Kestrels is therefore uncertain and should be examined in the context of vehicle collisions and noise levels. Other aspects of nestbox placement and design might affect nest success-and therefore population levels (e.g., Catry et al. 2009, McClure et al. 2016)-and should be examined. For instance, Smallwood et al. (2009b) demonstrated that the size of patches of suitable habitat affected the occupancy of nest boxes in New Jersey. Similar studies should examine nest success relative to cover type and landscape context. Predator guards can also increase nest success for cavity nesters (e.g., Cornell et al. 2011) and should therefore be examined for kestrels.

American Kestrels in Idaho have advanced nest initiation in response to climate change (Steenhof and Peterson 2009b, Heath et al. 2012, Anderson et al. 2016, Smith et al. 
2016). Although perhaps a reasonable assumption, it is unknown whether kestrels are responding to climate change across their range. The underlying mechanism regarding these phenology shifts (e.g., shifts in prey phenology, shorter migration distances) also deserves more study. Further, the demographic consequences of this response to climate change are unknown. Researchers should therefore use population models to examine whether the observed responses of American Kestrels to climate change are affecting populations levels.

Examining the Full Annual Cycle. Although important individually, survival and reproduction do not act in isolation-their interaction results in the growth or decline of a population. All population declines are therefore problems of demography, and a demographic understanding of the processes driving a population decline requires knowledge of the rates at which individuals immigrate into and emigrate from a population. Many nest-box programs for American Kestrels monitor reproduction, but do not track individuals and therefore it is unknown how observed levels of reproduction interact with other demographic processes to influence population levels. Given enough resources to both band individuals and monitor reproduction, nest-box programs can be powerful tools for studying not only fecundity and survival, but also immigration. For example, Brown and Collopy (2013) used integrated population models (Abadi et al. 2010) to examine how reproduction, survival, and immigration interact to produce a stable population of American Kestrels in Florida. Similar studies across declining and stable populations would allow for demographic comparisons where possibly depressed vital rates are identified as demographic mechanisms of decline.

Individual-based models track virtual individuals to examine emergent, population-level processes (Grimm and Railsback 2005) and are useful in studying demographic processes for migratory birds across multiple seasons (Hostetler et al. 2015). When combined with a pattern-oriented modeling approach, individual-based models can aid in the examination of processes that are not directly observed (Wiegand et al. 2003, Grimm et al. 2005), such as natal dispersal, emigration, and seasonal carry-over effects. For example, even though natural cavities are difficult to monitor, individual-based models could be used to evaluate the population-level effects of placing nest boxes into a landscape with natural cavities when the nest boxes either increase or decrease the reproductive rate of the population. In addition, these models offer the opportunity to synthesize knowledge on individual aspects of species dynamics to determine the interactive effect of population processes on overall population dynamics.

Ornithologists are recognizing the need for a fullannual-cycle, demographic understanding of population dynamics for migratory birds (Hostetler et al. 2015). Rushing et al. (2016) used information regarding migratory connectivity to compare drivers of Wood
Thrush (Hylocichla mustelina) declines on wintering versus breeding grounds. The problem of kestrel declines also requires a full-annual-cycle approach. Thus, data from across the annual cycle might be examined similarly for the American Kestrel. Simple solutions are unlikely to be found for the decline of a generalist predator that can thrive in human-modified habitat, with populations that range from fully migratory to completely sedentary, and with a range across two continents. Such an enigmatic decline as observed for the American Kestrel will therefore require examination into the full life cycle across breeding areas, migratory routes, and wintering grounds.

\section{COMENTARIO: RECOMENDACIONES DE INVESTIGACIÓN PARA ENTENDER LA DISMINUCIÓN POBLACIONAL DE FALCO SPARVERIUS A LO LARGO DE GRAN PARTE DE AMÉRICA DEL NORTE}

Resumen.-La naturaleza carismática y la enigmática disminución poblacional de Falco sparverius ha provocado el interés y la preocupación tanto de científicos (ciudadanos y profesionales) como del público en general. Aunque se han propuesto diversas razones como causas de esta disminución, hay poca o nula evidencia empírica para la mayoría de las amenazas hipotetizadas y consecuentemente no existen recomendaciones de gestión apoyadas en evidencia empírica. Presentamos recomendaciones para investigaciones futuras sobre la causa de la disminución poblacional de $F$. sparverius. Además, sugerimos prioridades para monitorear e identificar los condicionantes de las tasas de supervivencia y reproducción a través de modelos demográficos. Investigaciones sobre la fenología, la conectividad migratoria y el uso de cavidades naturales como nidos mejorarían el seguimiento de $F$. sparverius y nuestra comprensión sobre los declives poblacionales, mientras que estudios demográficos durante el ciclo anual completo de $F$. sparverius van a ayudar a elucidar las causas del declive y las acciones potenciales de gestión.

[Traducción del equipo editorial]

\section{ACKNOWLEDGMENTS}

No birds were handled for this work. We thank Ian Newton, Grainger Hunt, David Anderson, and Rick Watson for comments on earlier versions of this commentary. We thank the NSF Idaho EPSCoR Program (NSF award number IIA-1301792), the Boise State University Raptor Research Center, and the Department of Biological Sciences at Boise State University for project support. We also thank Judith King and Lynn and Jack Loacker for funding. We also thank Paul Spurling and the staff of The Peregrine Fund Research Library. No funders had any influence on the content of the submitted or published manuscript, nor did they require approval for the final manuscript to be published. 


\section{Literature Cited}

Abadi, F., O. Gimenez, B. Ullrich, R. Arlettaz, and M. SCHAUB. 2010. Estimation of immigration rate using integrated population models. Journal of Applied Ecology 47:393-400.

Anderson, A.M., S.J. Novak, J.F. SMith, K. SteEnhof, AND J.A. HEATH. 2016. Nesting phenology, mate choice, and genetic divergence within a partially migratory population of American Kestrels. Auk 133:99-109.

BÄChler, E., S. Hahn, M. Schaub, R. Arlettaz, L. Jenni, J.W. Fox, V. Afanasyev, and F. Liechti. 2010. Year-round tracking of small trans-Saharan migrants using light-level geolocators. PLOS ONE 5(3): e9566. https://doi.org/10. 1371/journal.pone.0009566 (last accessed 26 June 2017).

Bednarz, J.C., D. Klem, L.J. GoOdrich, And S.E. SEnNer. 1990. Migration counts of raptors at Hawk Mountain, Pennsylvania, as indicators of population trends, 19341986. Auk 107:96-109.

BILDSTEIN, K.L. 2004. Raptor migration in the Neotropics: patterns, processes and consequences. Ornitologia Neotropical 15:83-99.

— J.P. Smith, E. Ruelas I., AND R.R. VeIt. 2008. State of North America's birds of prey. Nuttall Ornithological Club, Cambridge, MA and The American Ornithologists' Union, Washington, DC U.S.A.

Bloom, P.H. and S.J. Hawks. 1983. Nest box use and reproductive biology of the American Kestrel in Lassen County, California. Raptor Research 17:9-14.

Bolgiano, N., J.-F. Therrien, And G. Grove. 2015. Pennsylvania's importance to American Kestrels. Pennsylvania Birds 29:76-83.

Bortolotti, G.R., R.D. Dawson, and G.L. Murza. 2002. Stress during feather development predicts fitness potential. Journal of Animal Ecology 71:333-342.

BRown, J.L. AND M.W. COLlOPY. 2013. Immigration stabilizes a population of threatened cavity-nesting raptors despite possibility of nest box imprinting. Journal of Avian Biology 44:141-148.

Butcher, G.S. 1990. Audubon Christmas Bird Counts. Pages 5-13 in J.R. Sauer and S. Droege [EDS.], Survey designs and statistical methods for the estimation of avian population trends. Biological Report 90(1). U.S.D.I. Fish and Wildlife Service, Washington, DC U.S.A.

- AND D.K. Niven. 2007. Combining data from the Christmas Bird Count and the Breeding Bird Survey to determine the continental status and trends of North America birds. National Audubon Society, Ivyland, PA U.S.A.

Catry, I., R. Alcazar, A.M.A. Franco, AND W.J. SutherLand. 2009. Identifying the effectiveness and constraints of conservation interventions: a case study of the endangered Lesser Kestrel. Biological Conservation 142:27822791.

Clark, M.E. And T.E. Martin. 2007. Modeling tradeoffs in avian life history traits and consequences for population growth. Ecological Modelling 209:110-120.
Cornell, K.L., C.R. Kight, R.B. Burdge, A.R. Gunderson, J.K. Hubbard, A.K. Jackson, J.E. LeClerc, M.L. Pitts, J.P. Swaddle, AND D.A. CRISTOL. 2011. Reproductive success of Eastern Bluebirds (Siala sialis) on suburban golf courses. Auk 128:577-586.

Craig, T.H. AND C.H. Trost. 1979. The biology and nesting density of breeding American Kestrels and Long-eared Owls on the Big Lost River, southeastern Idaho. Wilson Bulletin 91:50-61.

Di Fonzo, M., B. Collen, And G.M. Mace. 2013. A new method for identifying rapid decline dynamics in wild vertebrate populations. Ecology and Evolution 3:23782391.

Dudley, J. AND V. SAab. 2003. A field protocol to monitor cavity-nesting birds. Research Paper RMRS-RP-44. U.S.D.A. Forest Service, Rocky Mountain Research Station, Fort Collins, CO U.S.A.

DunCAN, B.W. 1985. American Kestrels banded at Hawk Cliff, Ontario 1972-1983. Ontario Bird Banding 17:3540.

Dunn, E., B. Altman, J. Bart, C. Beardmore, H. Berlanga, P. Blancher, G. Butcher, D. Demarest, R. Dettmers, W. Hunter, E. Iñigo-Elias, A. Panjabi, D. Pashley, C. Ralph, D. Rich, K. Rosenberg, C. Rustay, J. Ruth, And T. Will. 2005. High priority needs for range-wide monitoring of North American landbirds. Partners in Flight Technical Series No. 2. https://www.partnersinflight.org/ wp-content/uploads/2017/03/PIF-Technical-Series-02Monitoring-Needs.pdf (last accessed 3 July 2017).

FARMer, C.J., L.J. GoOdrich, E.R. InZunZA, And J.P. SMith. 2008. Conservation status of North America's birds of prey. State of North America's birds of prey. Series in Ornithology 3:303-420.

, D.J.T. Hussell, D. MizRahi, AND M. Bechard. 2007. Detecting population trends in migratory birds of prey. Auk 124:1047-1062.

, K. McCarty, S. Robertson, B. Robertson, And K.L. BILDSTEIN. 2006. Suspected predation by accipiters on radio-tracked American Kestrels (Falco sparverius) in eastern Pennsylvania, USA. Journal of Raptor Research 40:294-297.

_ _ AND J.P. SмITH. 2009. Migration monitoring indicates widespread declines of American Kestrels (Falco sparverius) in North America. Journal of Raptor Research 43:263-273.

Florida Fish and Wildlife Conservation Commission (FFWCC). 2013. A species action plan for the Southeastern American Kestrel Falco sparverius paulus. Florida Fish and Wildlife Conservation Commission, Tallahassee, FL U.S.A.

Fuller, M.R. AND J.A. Mosher. 1981. Methods of detecting and counting raptors: a review. Studies in Avian Biology 6:235-246.

GoOdrich, L.J., C.J. Farmer, D.R. Barber, K.L. Bildstein, AND J.P. SMITH. 2012. What banding tells us about the movement ecology of raptors. Journal of Raptor Research $46: 27-35$. 
Greenberg, R. And S. Droege. 1999. On the decline of the Rusty Blackbird and the use of ornithological literature to document long-term population trends. Conservation Biology 13:553-559.

Griggs, G.R. And K. Steenhof. 1993. Photographic guide for aging nestling American Kestrels. U.S.D.I., Raptor Research Technical Assistance Center, Boise, ID U.S.A.

Grimm, V. AND S.F. RAIlsBACK. 2005. Individual-based modeling and ecology. Princeton University Press, Princeton, NJ U.S.A.

—, E. Revilla, U. Berger, F. JeLtsch, W.M. MoOiJ, S.F. Railsback, H.-H. Thulke, J. Weiner, T. Wiegand, AND D.L. DeAngelis. 2005. Pattern-oriented modeling of agent-based complex systems: lessons from ecology. Science 310:987-991.

Hallmann, C.A., R.P.B. Foppen, C.A.M. Van Turnhout, H. De Kroon, and E. Jongejans. 2014. Declines in insectivorous birds are associated with high neonicotinoid concentrations. Nature 511:341-343.

Hamerstrom, F., F.N. Hamerstrom, AND J. HART. 1973. Nest boxes: an effective management tool for kestrels. Journal of Wildlife Management 37:400-403.

Hayward, G.D., R.K. Steinhorst, And P.H. Hayward. 1992. Monitoring Boreal Owl populations with nest boxes: sample size and cost. Journal of Wildlife Management 56:777-785.

Heath, J.A., K. Steenhof, And M.A. Foster. 2012. Shorter migration distances associated with higher winter temperatures suggest a mechanism for advancing nesting phenology of American kestrels Falco sparverius. Journal of Avian Biology 43:376-384.

Henny, C.J. And G.L. BRAdy. 1994. Partial migration and wintering localities of American Kestrels nesting in the Pacific Northwest. Northwestern Naturalist 75:37-43.

Hinnebusch, D.M., J.-F. Therrien, M.-A. Valiquette, B. Robertson, S. Robertson, and K.L. Bildstein. 2010. Survival, site fidelity, and population trends of American Kestrels wintering in southwestern Florida. Wilson Journal of Ornithology 122:475-483.

Hiraldo, F., J.J. Negro, J.A. Donázar, and P. GaOna. 1996. A demographic model for a population of the endangered Lesser Kestrel in southern Spain. Journal of Applied Ecology 33:1085-1093.

Hoffman, S.W., J.P. Smith, and T.D. Meehan. 2002. Breeding grounds, winter ranges, and migratory routes of raptors in the mountain west. Journal of Raptor Research 36:97-110.

Hostetler, J.A., T.S. Sillett, And P.P. Marra. 2015. Fullannual-cycle population models for migratory birds. Auk 132:433-449.

Katzner, T., S. Robertson, B. Robertson, J. Klucsarits, K. MCCARTY, AND K.L. BILDSTEIN. 2005. Results from a longterm nest-box program for American Kestrels: implications for improved population monitoring and conservation. Journal of Field Ornithology 76:217-226.

Klucsarits, J.R. AND J. RusBuldt. 2007. A photographic timeline of Hawk Mountain Sanctuary's American
Kestrel nestlings. Zip Publishing, Columbus, OH U.S.A.

Lambrechts, M.M., K.L. Wiebe, P. Sunde, T. Solonen, F. Sergio, A. Roulin, A.P. Møller, B.C. López, J.A. Fargallo, K.M. Exo, G. Dell'Omo, D. Costantini, M. Charter, M.W. Butler, G.R. Bortolotti, R. ArlettaZ, AND E. KorpimäKI. 2012. Nest box design for the study of diurnal raptors and owls is still an overlooked point in ecological, evolutionary and conservation studies: a review. Journal of Ornithology 153:23-34.

Loss, S.R., T. Will, AND P.P. MARRA. 2015. Direct mortality of birds from anthropogenic causes. Annual Review of Ecology, Evolution, and Systematics 46:99-120.

LotT, C.A. 2006. A new raptor migration monitoring site in the Florida Keys: counts from 1999-2004. Journal of Raptor Research 40:200-209.

Mace, G.M., N.J. Collar, K.J. Gaston, C. Hilton-Taylor, H.R. AKÇAKaya, N. Leader-Williams, E.J. Milner-GulLAND, AND S.N. STUART. 2008. Quantification of extinction risk: IUCN's system for classifying threatened species. Conservation Biology 22:1424-1442.

McClure, C.J.W., N.D. Burkett-CAdena, R.A. LigOn, AND G.E. HiLL. 2011. Actual or perceived abundance? Interpreting annual survey data in the face of changing phenologies. Condor 113:490-500.

- B.P. Pauli, and J.A. Heath. 2017. Simulations reveal the power and peril of artificial breeding sites for monitoring and managing animals. Ecological Applications 27: 1155-1166.

,-- B. MutCh, AND P. Juergens. 2016. Assessing the importance of artificial nest sites for the population dynamics of endangered Northern Aplomado Falcons Falco femoralis septentrionalis in south Texas using stochastic simulation models. Ibis 159:14-25.

Miller, K.E. AND J.A. Smallwood. 2009. Breeding-site fidelity of Southeastern American Kestrels (Falco sparverius paulus). Journal of Raptor Research 43:369-371.

Mineau, P. AND C. PAlmer. 2013. The impact of the nation's most widely used insecticides on birds. American Bird Conservancy. http://www.abcbirds.org/abcprograms/ policy/toxins/Neonic_FINAL.pdf (last accessed 3 July 2017).

NAGY, A.C. 1963. Population density of sparrow hawks in eastern Pennsylvania. Wilson Bulletin 75:93.

Nemeth, N., D. Gould, R. Bowen, and N. Komar. 2006. Natural and experimental West Nile virus infection in five raptor species. Journal of Wildlife Diseases 42:1-13.

Nolte, E.G., J. Bart, B.P. Pauli, G.S. Kaltenecker, And J.A. HEATH. 2016. Detectability of migrating raptors and its effect on bias and precision of trend estimates. Avian Conservation and Ecology 11(2):9.

Paprocki, N., J.A. HEATH, AND S.J. Novak. 2014. Regional distribution shifts help explain local changes in wintering raptor abundance: implications for interpreting population trends. PLOS ONE 9(1): e86814. 
https://doi.org/10.1371/journal.pone.0086814 (last accessed 26 June 2017)

, D. Oleyar, D. Brandes, L. Goodrich, T. Crewe, AND S.W. Hoffman. 2017. Combining migration and wintering counts to enhance understanding of population change in a generalist raptor species, the North American Red-tailed Hawk. Condor 119:98:107.

RatTner, B.A., K.E. HoraK, R.S. Lazarus, S.L. Schultz, S. Knowles, B.G. AbBo, And S.F. Volker. 2015. Toxicity reference values for chlorophacinone and their application for assessing anticoagulant rodenticide risk to raptors. Ecotoxicology 24:720-734.

Ruegg, K.C., E.C. Anderson, K.L. Paxton, V. Apkenas, S. Lao, R.B. Siegel, D.F. Desante, F. Moore, and T.B. SMITH. 2014. Mapping migration in a songbird using high-resolution genetic markers. Molecular Ecology 23:5726-5739.

Rushing, C.S., T.B. Ryder, P.P. MARRA, AND C.S. Rushing. 2016. Quantifying drivers of population dynamics for a migratory bird throughout the annual cycle. Proceedings of the Royal Society B: Biological Sciences 283:20152846.

Sether, B.-E. AND Ø. Bakke. 2000. Avian life history variation and contribution of demographic traits to the population growth rate. Ecology 81:642-653.

Sauer, J.R., J.E. Hines, J.E. Fallon, K.L. Pardieck, D.J. Ziolkowski, AND W.A. Link. 2014. The North American Breeding Bird Survey, results and analysis 1966-2012. Version 02.19.2014. U.S.G.S. Patuxent Wildlife Research Center, Laurel, MD U.S.A.

Shommaker, K.T. AND H.R. AKÇAKaya. 2014. Inferring the nature of anthropogenic threats from long-term abundance records. Conservation Biology 29:238-249.

Simons, T.R., M.W. Alldredge, K.H. Pollock, J.M. Wettroth, And A.M. Dufty. 2007. Experimental analysis of the auditory detection process on avian point counts. Auk 124:986-999.

SMAllwoOD, J.A. AND D.M. BIRD. 2002. American Kestrel (Falco sparverius). In P.G. Rodewald [ED.], The birds of North America. Cornell Lab of Ornithology, Ithaca, NY U.S.A. https://birdsna.org/Species-Account/bna/ species/amekes (last accessed 25 June 2017).

- M.F. Causey, D.H. Mossop, J.R. Klutcsarits, B. Robertson, S. Robertson, J. Mason, M.J. Maurer, R.J. Melvin, AND R.D. Dawson. 2009a. Why are American Kestrel (Falco sparverius) populations declining in North America? Evidence from nest-box programs. Journal of Raptor Research 43:274-282.

— AND M.W. Collopy. 2009. Southeastern American Kestrels respond to an increase in the availability of nest cavities in north-central Florida. Journal of Raptor Research 43:291-300.

—, P. Winkler, G.I. Fowles, and M.A. Craddock. 2009b. American Kestrel breeding habitat: the importance of patch size. Journal of Raptor Research 43:308-314.

SMith, S.H., K. STEENHOF, C.J.W. MCCluRE, AND J.A. HEATH. 2016. Earlier nesting by generalist predatory bird is associated with human responses to climate change. Journal of Animal Ecology 86: 98-107.

StAHLECKER, D.W. AND H.J. GRIESE. 1979. Raptor use of nest boxes and platforms on transmission towers. Wildlife Society Bulletin 7:59-62.

Stanton, J.C., B.X. Semmens, P.C. McKann, T. Will, And W.E. Thogmartin. 2016. Flexible risk metrics for identifying and monitoring conservation-priority species. Ecological Indicators 61:683-692.

Steenhof, K. And J.A. Heath. 2009. American Kestrel reproduction: evidence for the selection hypothesis and the role of dispersal. Ibis 151:493-501.

AND - 2013. Local recruitment and natal dispersal distances of American Kestrels. Condor 115:584-592.

- AND B. Peterson. 2009a. Site fidelity, mate fidelity, and breeding dispersal in American Kestrels. Wilson Journal of Ornithology 121:12-21.

- AND - 2009b. American Kestrel reproduction in southwestern Idaho: annual variation and long-term trends. Journal of Raptor Research 43:283-290.

Strasser, E.H. AND J.A. Heath. 2013. Reproductive failure of a human-tolerant species, the American Kestrel, is associated with stress and human disturbance. Journal of Applied Ecology 50:912-919.

Stupik, A.E., T. Sayers, M. Huang, T.A.G. Rittenhouse, AND C.D. RitTENHOUSE. 2015. Survival and movements of post-fledging American Kestrels hatched from nest boxes. Northeastern Naturalist 22:20-31.

Sullivan, B.L. AND C.L. Wood. 2005. The changing seasons: a plea for the common birds. North American Birds 59:18-30.

TOLAND, B.R. AND W.H. ELDER. 1987. Influence of nest-box placement and density on abundance and productivity of American Kestrels in central Missouri. Wilson Bulletin 99:712-717.

VAN BuskiRK, J. 2012. Changes in the annual cycle of North American raptors associated with recent shifts in migration timing. Auk 129:691-698.

— R.S. MulvihiLl, AND R.C. Leberman. 2009. Variable shifts in spring and autumn migration phenology in North American songbirds associated with climate change. Global Change Biology 15:760-771.

VAnCAMP, L.F. AND C.J. Henny. 1975. The screech owl: its life history and population ecology in northern Ohio. North American Fauna 71:1-65.

Van Strien, A.J., J. Pannekoek, and D.W. Gibbons. 2001. Indexing European bird population trends using results of national monitoring schemes: a trial of a new method. Bird Study 48:200-213.

VARLAND, D.E. AND T.M. LoughIN. 1993a. Use of habitat and perches, causes of mortality and time until dispersal in post-fledging American Kestrels. Journal of Field Ornithology 64:169-178.

- AND ——. 1993b. Reproductive success of American Kestrels nesting along an interstate highway in central Iowa. Wilson Bulletin 105:465-474. 
Viverette, C.B., S. Struve, L.J. Goodrich, And K.L. Bildstein. 1996. Decreases in migrating Sharpshinned Hawks (Accipiter striatus) at traditional raptor-migration watch sites in eastern North America. Auk 113:32-40.

Wiegand, T., F. Jeltsch, I. Hanski, and V. GRimm. 2003. Using pattern-oriented modeling for revealing hidden information: a key for reconciling ecological theory and application. Oikos 65:209-222.
WiLMERS, T.J. 1983. Kestrel use of nest boxes on reclaimed surface mines in West Virginia and Pennsylvania. Journal of Raptor Research 17:30-31.

Wommack, E.A., R.D. Dawson, J.M. Shrimpton, And R.C.K. BowIE. 2014. Changes in population size and genetic diversity of a raptor species occurring in the boreal forest of Saskatchewan. Conservation Genetics 16:535547.

Received 15 August 2016; accepted 15 February 2017 